\title{
MED7 wt Allele
}

National Cancer Institute

\section{Source}

National Cancer Institute. MED7 wt Allele. NCI Thesaurus. Code C52212.

Human MED7 wild-type allele is located in the vicinity of $5 q 33.2$ and is approximately $7 \mathrm{~kb}$ in length. This allele, which encodes mediator of RNA polymerase II transcription subunit 7 protein, is involved in transcriptional initiation. 